\title{
CONGENITAL PYLORIC STENOSIS IN FIRST AND SECOND COUSINS
}

\author{
BY
}

\author{
E. A. COCKAYNE, D.M., F.R.C.P.
}

In 1934 I published two pedigrees of congenital pyloric stenosis in first cousins, and now I present three more of the same kind and a fourth in which the affected children were second cousins.

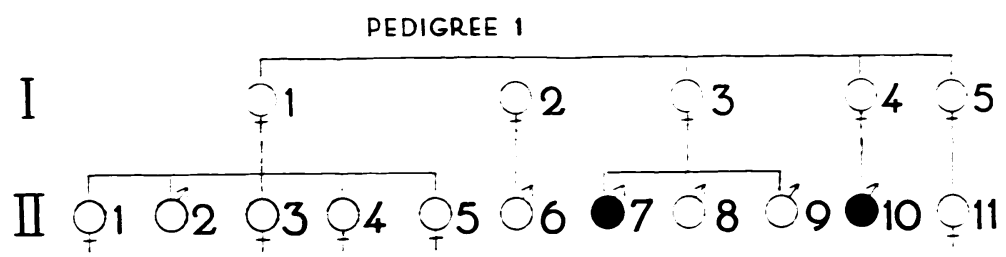

\section{Case Records}

Pedigree 1.-T. M., a male, aged five years, was admitted to the Hospital for Sick Children five years ago under the care of Dr. R. S. Frew with projectile vomiting and constipation. He had visible peristalsis and a tumour was felt. He was operated on at the age of five weeks on December 26, 1932, the diagnosis was confirmed, and he recovered. His first cousin, A. P., was admitted under the care of Dr. D. Paterson with similar symptoms, and the diagnosis of pyloric stenosis was confirmed at operation on September 14, 1937. He also recovered. I am indebted to the father of A. P. for the care he took in completing the pedigree.

I.1, female, aged forty-one, has five normal children born in the following order, a daughter, a son, and three daughters, aged respectively, seventeen, sixteen, fourteen, twelve and six years ; II. 1, 2, 3, 4, and 5. I.2, female, aged thirty-two, has one normal son, aged seven years, II.6. I.3, female, aged thirty, has three sons, the eldest, T. M., II.7, aged five, who had pyloric stenosis, and two younger ones, aged three and one-and-a-half, II.8 and 9, who are normal. I.4, female, aged twenty-eight, has one son, A. P., II.10, who had pyloric stenosis. I.5, female, aged twenty-four, has one daughter, aged two years, II.11, who is normal. Neither marriage which produced offspring with pyloric stenosis was consanguineous, and no other cases are known to have occurred in the family. 


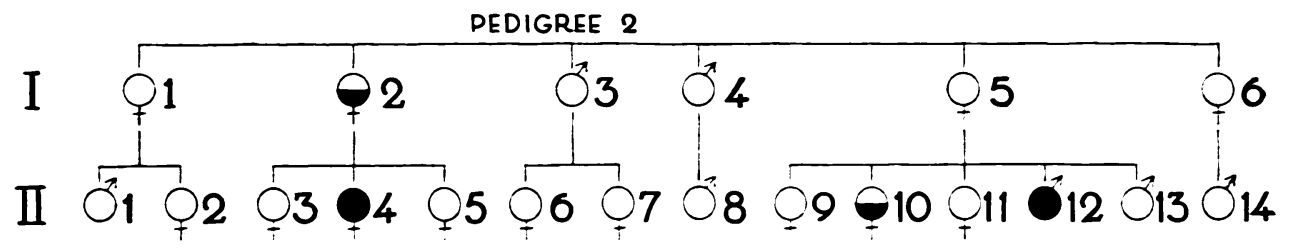

Pedigree 2.-For this pedigree I am indebted to Dr. R. R. Lane of Bolsover, who took great trouble to make it full and accurate. The ages are correct for November, 1937. I.1, female, aged forty-nine, has a son, II.1, aged twenty-two, and a daughter, II.2, aged ten both normal. I.2, female, aged forty-seven, as an infant had vomiting and constipation attributed to pylorospasm, and recovered with medical treatment. She had three daughters, the eldest, II.3, and the youngest, II.5, were normal, but the middle one, II.4, had pyloric stenosis verified at operation and died. I.3, male, aged forty-five, has two daughters, II.6 and 7, aged sixteen and fourteen, both normal. I.4, male, aged forty-three, had a son, II.8, who died at the age of four days. I.5, female, aged thirty-nine, has a normal daughter, II.9, aged ten ; a daughter, II.10, aged seven, who in the first weeks of life had vomiting, constipation, and loss of weight, diagnosed as pylorospasm, and recovered with medical treatment ; a normal daughter, II.11, aged six ; a son, II.12, aged four who had pyloric stenosis, confirmed at operation, and recovered ; and a son, II.13, aged two years, who is normal. I.6, female, aged thirty-six, has a normal son, II.14, aged nine years. Neither marriage which gave rise to a child with pyloric stenosis was consanguineous. It is interesting that the mother of the girl with pyloric stenosis and a sister of the boy with pyloric stenosis, her first cousin, both had an illness in babyhood which was diagnosed as pylorospasm. It is possible that this was a mild form of the disorder or at least a manifestation of the same gene.

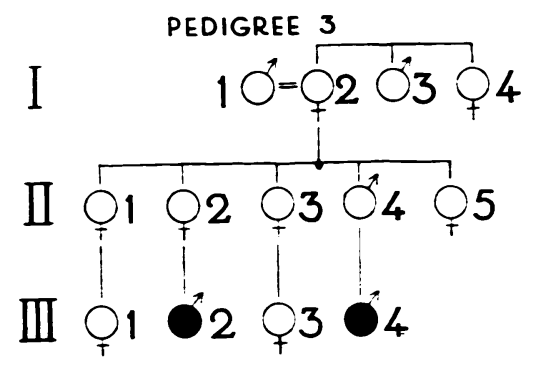

Pedigree 3.-A. M., a male, aged two months, admitted to the Hospital for Sick Children under my care in June, 1937, suffered from vomiting and constipation and had visible peristalsis and a palpable tumour. The diagnosis of pyloric stenosis was confirmed at the operation and he was discharged on June 17, but was readmitted later with gastro-enteritis and died on July 18 .

His first cousin, a boy, suffered from vomiting at the age of six weeks and shortly afterwards died from pneumonia with convulsions. His symptoms are said to have been like those of A. M. and his doctor told the parents that he had an obstruction in his stomach. Owing to the attack of pneumonia no operation could be performed and the diagnosis was not fully confirmed, but there can be little doubt that it was correct. 
The grandparents are said to have been normal and the grandmother, I.2, had a brother and sister, I.3 and 4, both normal and both unmarried. II.1, female, aged thirty-six, has one child, III.1, a normal daughter. II.2, female, aged twenty-seven, has a son, III.2, the patient A. M. II.3, female, has one child, III.3, a normal daughter. II.4, male, had only one child, III.4, who died probably from pyloric stenosis. II.5, female, aged nineteen, is unmarried.

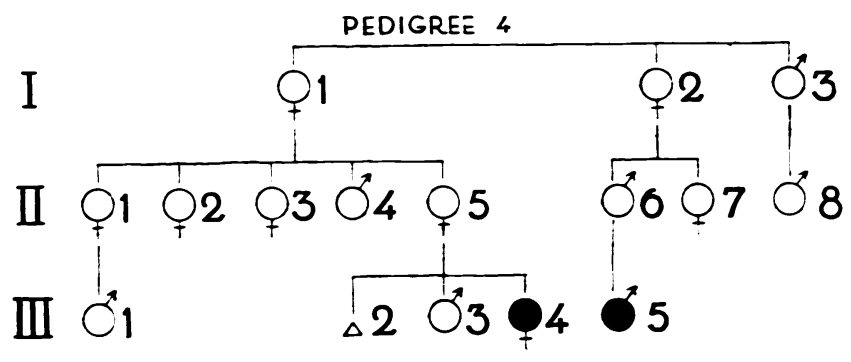

Pedigree 4.-M. E. S., a female born in 1934, was admitted to the Hospital for Sick Children under the care of Dr. R. S. Frew with vomiting, constipation, and visible peristalsis. The diagnosis of pyloric stenosis was verified at operation, and she recovered. H. L., her second cousin, a male, born in September, 1933, was operated on for pyloric stenosis and died at the age of six weeks. The diagnosis was confirmed, The father of M. E. S. took considerable trouble to compile a complete and accurate pedigree of his near relations.

I.1, female, has five children, all normal, three daughters, II.1, 2, and 3, a son, II.4, and a daughter, II.5. The eldest has one son, III.1, born in 1921, who is normal. The second and third are unmarried. The fourth, a male born in 1901, died at the age of thirteen weeks, but not from pyloric stenosis. The fifth, II.5, has had three pregnancies. The first ended in a miscarriage. The first living child, III.3, born in 1932, is normal, and the second, M. E. S., III.4, a girl, had pyloric stenosis. I.2, female, has two children. The elder, H. J. L., II.6, had only one child, the boy, R. L., III.5, who died of pyloric stenosis. The younger, II.7, who married in July, 1934, has no children. I.3, male, has only one child, II.8, a normal son.

Neither marriage which produced a child with pyloric stenosis was consanguineous, and no other cases are known to have occurred in the family.

\section{Discussion}

The etiology of congenital pyloric stenosis is still a matter in dispute, but there can be no doubt that heredity plays a most important part, if it is not the sole factor concerned. Many examples of its incidence in two or even three members of the same fraternity have been published and collected by Halbertsma (1935) and others, and there are several records of its occurrence in both members of a pair of monozygotic twins, collected by Sheldon (1938). The exact mode of inheritance is, however, still uncertain.

The great excess of males with the condition suggests that a sex-linked gene, recessive or incompletely dominant, is concerned, though the family histories 
make it unlikely that it is determined solely by a sex-linked gene. The pedigrees published previously (Cockayne, 1934) and in this paper prove that it cannot be determined by a sex-linked gene acting alone. No such gene can be transmitted from father to son, because the $\mathrm{X}$-chromosome of the male in man goes to his daughters, and only the Y-chromosome goes to his sons. Pedigrees in which first and second cousins have the condition are the best means of discovering whether a male can transmit pyloric stenosis to his son, because one may reasonably assume that when two sibs have children or grandchildren with the condition, they are the transmitters. Pyloric stenosis is not uncommon and coincidence might account for occasional instances in which the unrelated parent transmitted it to one of the affected cousins, but such cases would be rare in comparison with the others.

In these six pedigrees there are three instances of a man transmitting pyloric stenosis to his son. The pedigree published by Halbertsma affords a fourth instance and so increases the evidence against its determination by a single sex-linked gene.

In this interesting pedigree the grandparents were both normal, but they had a son with pyloric stenosis and a son and a daughter who were apparently normal. Of these two normal children the daughter had two sons with pyloric stenosis and a normal son, while the son had a daughter with pyloric stenosis, a normal son and a son with pyloric stenosis. Thus two boys with the condition in the one fraternity were first cousins to a boy and girl with it in the other fraternity, and there can be no doubt that an apparently normal man transmitted the condition to his son.

These pedigrees, however, do not prove that the condition is not determined by two independent genes, one sex-linked and the other autosomal. If this is the case the figures agree better with a dominant than a recessive autosomal gene. There are only one or two known cases of direct transmission of the condition from parent to child, and ignoring these the ratio of males to females with pyloric stenosis would be $5: 1$, assuming it to be determined by a recessive sex-linked gene and an autosomal dominant, and transmission of the sex-linked gene would be through the female alone in ten and through both parents in two of the twelve possible matings. The ratio of males to females with pyloric stenosis is at least $5: 1$ and agrees well with that expected on this hypothesis, and the ratio of female transmitters to male transmitters is $11: 3$ or with Halbertsma's pedigree $12: 4$ instead of the expected $10: 2$. There are, however, difficulties in the way of accepting this hypothesis, such as the rarity of consanguineous marriages and the low ratio of affected to normal children in the fraternities, apart from the fact that determination by two genes is less likely than determination by one.

An incompletely dominant gene with partial sex-limitation to the male would give results very like those actually found. It is clear that the mode of inheritance of congenital pyloric stenosis still awaits an explanation, but a large collection of pedigrees of the kind published in this paper would afford great help in solving this difficult problem. 


\section{Summary}

(1) Four new pedigrees illustrating the occurrence of congenital pyloric stenosis in first and second cousins are published.

(2) In these four pedigrees, the two published in 1934, and Halbertsma's there are four instances of a man transmitting pyloric stenosis to his son.

(3) This proves that the condition is not determined by a single sex-linked gene, recessive or incompletely dominant, but does not exclude the possibility that it is determined by a sex-linked gene acting with an autosomal dominant gene.

Thanks are due to Dr. R. Frew and Dr. D. Paterson for permission to publish their cases.

\section{REFERENCES}

Cockayne, E. A. (1934). Lancet, 1, 898.

Halbertsma, Tj. (1935). Maandschr. v. Kindergeneesk., 5, 24.

Sheldon, W. (1938). Lancet, 1, 1048. 